\title{
A Unique Governance Learning Experience
}

Margo Baptista

Grant MacEwan University

\begin{abstract}
This paper reports on some of the findings of a 2008-2009 graduate study conducted as a shared organizational learning experience for the Grant MacEwan College (now MacEwan University ${ }^{1}$ ) Board of Governors to learn about a vital board governance responsibility-presidential search. Through a facilitated, qualitative action research exercise, participants engaged in a four-stage progressive learning experience to create a body of knowledge about presidential search experiences and to develop strategies for transferring this knowledge when membership changes. The study examined how, through the application of knowledge management theory, a board can learn and share knowledge. This learning experience contributed to the creation of a comprehensive board succession plan for the MacEwan Board of Governors and, in 2010-2011, this plan was used to guide the institution's search for its fourth president.
\end{abstract}

\section{Résumé}

Cet article présente quelques-unes des conclusions d'une recherche menée en 2008-2009 auprès du Conseil des Gouverneurs du Grant MacEwan College $\left(\right.$ MacEwan $\left.^{2}\right)$. Organisée sous la forme d'une expérience d'apprentissage organisationnelle, l'étude visait à permettre aux membres du Conseil de s'approprier une des responsabilités cruciales des conseils en matière de gouvernance : l'embauche d'un président. Au fil d'une recherche-action qualitative et encadrée, les membres du Conseil ont été amenés à s'engager dans un processus d'apprentissage progressif en quatre étapes leur permettant de mutualiser leurs connaissances et leurs expériences au sujet de l'embauche d'un président, et ainsi de créer des stratégies pour transférer ce corps de connaissances et d'expériences au fil des changements dans la composition du Conseil. L'étude a ainsi pu examiner la façon dont un conseil peut apprendre et partager les savoirs en mettant en pratique la théorie de la gestion des 
connaissances. Cette expérience unique a mené à la réalisation d'un plan de transition exhaustif pour le Conseil et, en 2010-2011, a également soutenu le processus d'embauche du quatrième président de MacEwan.

\section{Introduction}

The frequency of turnover within postsecondary boards of governors presents particular challenges to the individual and collective ability of board members to acquire and manage intellectual capital on their roles and responsibilities. In 2008-2009, a graduate study examined how, through the application of knowledge management theory, a board can learn and share knowledge on a vital board responsibility-presidential search. Board members may learn about the topic of presidential search through presentations at governance conferences or by reading governance books. Most often, however, boards learn about the topic at the time, experientially, their institution is engaged in the recruitment process for its next president. Seeking knowledge about this topic through a proactive and targeted approach is not common practice. However, in 2008, the board of governors at Grant MacEwan College (now MacEwan University) embraced a unique opportunity to learn about presidential search at a time when the institution was not conducting a search. Through a facilitated, qualitative action research exercise, participants engaged in a four-stage progressive learning experience to create a body of knowledge about presidential search experiences and to develop strategies for transferring this knowledge when board membership changes. This shared organizational learning experience contributed to the creation of a comprehensive board succession plan for the MacEwan Board of Governors and, in 2010-2011, this plan was used to guide the institution's search for its fourth president.

This action research project studied the main research question "How can the Grant MacEwan College Board of Governors acquire and transfer knowledge about presidential searches?" The supplementary questions were as follows:

1. What techniques do boards use to gather information about presidential searches?

2. How do boards consider best practices when developing search processes?

3. What role do external recruitment specialists play in board member education about best practices in presidential search?

4. How is information about presidential searches transferred when board members change?

5. How can the Grant MacEwan College Board of Governors translate this knowledge into a plan for its next presidential search?

Boards of governors function as the ultimate authority of the institution and are in a fiduciary relationship with the province. In Alberta, the authority, roles, and responsibilities of such boards are outlined in the Post-Secondary Learning Act (2003); they include setting policy, undertaking strategic planning (e.g., academic, financial, and capital), and providing oversight and audit. Institutions use various means to facilitate board members' learning about these functions, including orientation programs, meeting agendas, retreats, conferences, committee assignments, organization documents, institutional events and activities, and governance books and articles. Within these institutions, boards are supported by a professional resource staff person who manages many of these 
strategies. In addition, members can participate in formal board development programs through government departments, member organizations, and educational institutions. MacEwan's board of governors employs all of these learning strategies.

Chait, Holland, and Taylor (1993) defined education as one of six competencies of effective boards and posited that strong boards consciously create opportunities to educate trustees about the institution as well as board roles and responsibilities. Neff and Leondar (1992) observed that "a presidential search is the most important task a governing board undertakes" (p. xv). Block McLaughlin (1993) commented, "No other event in the life of an institution affords the same opportunity for institutional learning as does the search for a president” (p. 113). In its 38-year history, Grant MacEwan College had recruited three presidents who had led the institution through distinct phases of its evolution. It was within the context of preparing for the next presidential search and having the opportunity to experience a new learning strategy that the topic of presidential search was chosen to be explored within the study.

This four-stage study was conducted between September 2008 and January 2009. Study participants $(N=23)$ included internally elected and publicly appointed board members, primarily board chairs, from public postsecondary institutions in Alberta and British Columbia. Members of the MacEwan board $(n=12)$ volunteered to participate in the study, 9 of whom participated in the four stages. The other participants were board chairs $(n=12)$, who had participated in presidential searches and recruitment specialists $(n=2)$, who provide executive search services to public postsecondary institutions in both provinces. Four of the board chairs and the two recruitment specialists participated in two phases, the survey and focus groups. The study was designed as a shared learning exercise with four data-gathering stages used to explore theoretical constructs related to knowledge management, knowledge transfer, and board succession planning. The four stages comprised an online survey, mini focus groups, one-on-one semi-structured interviews, and a modified World Café ${ }^{\square}$ (see Table 1). Each stage of learning was sequenced to build upon the preceding one and cover the three topics of the study: knowledge management within a board of governors, board succession planning, and presidential search. Principal findings were grouped within five thematic areas: knowledge management within a board of governors, knowledge transfer within a board of governors, board succession planning, the learning topic-presidential search, and the learning experience of the participants. This paper focuses on the fifth theme, the learning experience.

Table 1.

Data Collection Methods and Number of Participants

\begin{tabular}{lccc}
\hline Method & Total Participants & External Participants & MacEwan Participants \\
\hline Online survey & 23 & 14 & 9 \\
Focus groups & 12 & 6 & 6 \\
Interviews & 9 & 0 & 9 \\
World Café & 9 & 0 & 9 \\
\hline
\end{tabular}




\section{Theoretical Constructs}

Three primary theoretical constructs underpinned this study: knowledge management, knowledge transfer, and board succession planning. These constructs guided an action research exercise, within which participants acquired and transferred knowledge on the topic of presidential search. The following literature review provides an understanding of how knowledge is defined, generated, acquired, transferred, and sustained.

\section{Knowledge Management}

Williams (2006) used the notion of articulation to comment on the implicit nature of data, information, and knowledge, noting that each level builds upon the previous and, therefore, implicitly contains parameters from that domain. Data are found in information, which in turn articulates to knowledge; conversely, knowledge contains elements of information and data, with the added ingredient of context. Nonaka and Takeuchi's SECI model from 1995 (as cited in Nonaka, 2002) outlined four modes for converting tacit knowledge from individuals into shared, explicit knowledge: socialization, externalization, internalization, and combination. In this model, knowledge is viewed as moving through cycles of continual learning that eventually resemble a spiral when deeper and deeper levels of understanding are reached (Nonaka, 2002). Wenger's (2004) concept of communities of practice is a cornerstone principle of knowledge management, defined as knowledge domains, problems, or situations in which people with a shared passion for and experience with a particular knowledge interact regularly in order to learn. Practice is the experience needed to produce "the body of knowledge, methods, tools, stories, cases, and documents which members share and develop together" (p. 3). Chait, Ryan, and Taylor (2005) suggested, "Boards act as communities of practice [,] creating multiple opportunities for the entire board or particular committees to pool usable knowledge and thereby learn together" (p. 144).

From an organizational learning perspective, Huysman and de Wit's (2003) framework depicted how organizational and external knowledge is retrieved, created, and exchanged by individuals and subsequently translated into shared organizational learning. Acknowledging that individual learning is less complicated and easier to manage than organizational learning, Huysman and de Wit maintained that collective learning must be a priority if organizations are to experience success in their knowledge management initiatives.

\section{Knowledge Transfer}

Argote (1999) identified interpersonal knowledge as a key building block of organizational learning and suggested that organizations need to facilitate group learning through four processes: (a) acquiring knowledge by importing or sharing knowledge already existing within or outside the group, (b) generating new knowledge through collaboration and interaction, (c) evaluating knowledge that has been shared or generated, and (d) combining knowledge into a collective product. Snowden's (2005) use of a social network analysis tool reached a similar conclusion, namely that "knowledge creation and exchange, together with learning mechanisms, require forms of community interaction" (p. 561). Lucas and Ogilvie (2006) observed that successful knowledge transfer is based on whether or not the sender and receiver see one another as partners, know one another well, and "view knowledge as something to be shared with their colleagues" (p. 18). 


\section{Board Succession Planning}

Bugg and Dallhoff's (2006) National Study of Board Governance Practices in the Non-Profit and Voluntary Sector in Canada identified board succession planning as well as recruitment, orientation, and training as critical governance practices. In addition to having a well-organized orientation program, Buff and Dallhoff recommended finding resources to continually educate, train, and develop board members in governance work. The educational dimension of boards was explored by Chait et al. (1993), who stated, "Effective boards take the necessary steps to ensure that [members] are well-informed about the institution and about the board's roles, responsibilities, and performance" (p. 26). They encouraged boards to take a conscious and ongoing approach to members' orientation and development through a variety of informal and formal strategies. Smith (2000) cited as a defining characteristic of effective boards that "they are learning boards for their learning colleges" (p. 198). By making learning a priority for themselves and their colleges, boards ultimately make a better contribution to their colleges. Commenting on the intellectual capital of boards, Chait et al. (2005) observed, "Intellectual capital is not the sum of trustees' knowledge...[rather,] effective boards and successful companies require shared knowledge" (p. 143), so that governance as leadership can flourish.

\section{Methodology}

This study used action research as its primary methodology, utilizing an appreciative inquiry process. The method focused on qualitative data gathering and analysis, combined with some quantitative data gathering and analysis. Appreciative inquiry is a collaborative and participative approach, which relies on interactive techniques such as group discussion and interviews to create a consultative environment that allows for generative dialogue and reflection. This social process of joint inquiry provided the opportunity to embrace the lived experiences of participants: context, background, and values. Through this research project, participants had a unique opportunity, in their roles as board members, to go beyond casual conversation to have an in-depth dialogue about and analyze the presidential search processes. The participatory philosophy of action research was pertinent to this study, as each participant had something to contribute to the dialogue and the solution. Equally important was the reflective nature of action research, whereby participants had the opportunity to reflect on their experiences as well as the experiences of others.

Participants explored the main research question and supplementary questions by sharing their experiences and perspectives through the lens of governance in the public postsecondary system. This study inquired about strategies used to acquire and transfer explicit and tacit knowledge. The second theme explored in the study, knowledge transfer, examined techniques and strategies used by boards to share knowledge. The study also inquired as to how boards develop and manage their succession plan, including best practices for board succession planning. Regarding presidential search, the study identified and explored 18 distinct components of this process (see Table 2). It also explored best practices for presidential search and strategies for learning about it. The last theme of the study examined the value of the learning experience for the various participants. 
Table 2.

Distinct Components of a Presidential Search Identified and Explored Through the Study

1. Search process

2. Search timeline

3. Search committee models

4. Membership

5. Committee chair

6. Role of the board and committee terms of reference

7. Stakeholder consultation and engagement

8. Policy, practice, plan or guidelines

9. Board visioning exercise

10. Position profile

11. Recruitment specialist

12. Role of human resources department

13. Interim president

14. Transition plan

15. Communication strategy

16. Confidentiality

17. Political sensitivities and ethical issues needing consideration

18. Organizational culture

The researcher conducted a four-stage data-gathering exercise that comprised an online survey, focus group sessions, one-on-one interviews, and a World Café group activity. Each stage of the inquiry process required data analysis before proceeding to the next activity. Data from the focus group sessions and one-on-one interviews were analyzed thematically to understand the data within the participants' context and the setting, as well as to identify themes and questions to be explored in the fourth and final activity, the World Café. The use of multiple iterative data-gathering methods in this study was a deliberate choice so as to triangulate the perspectives of participants on each topic. This approach was based upon triangulation theory, as put forth by Glesne (2006), who advocated for depth and repeated interaction with a small group of participants rather than greater breadth and single observation. Berg (2004) had a similar suggestion. Using the phrase "multiple lines of sight" (p. 5), Berg advised researchers to strive for more than two sighting lines to obtain deeper verification and validation of the matter being investigated.

\section{Stage 1. Online Survey}

The online survey gathered basic information on the three primary topics (knowledge management, board succession planning, and presidential search) from 23 respondents. In terms of learning about presidential search, participants responded to questions (Appendix A) inquiring how they learned about conducting a presidential search process and 
about all of the elements involved in a search. They indicated whether or not their knowledge was based on any of the following sources: past experience with a search process while on a current board or another board, a board education or development plan, attending a conference, attending presentations by industry experts or paid consultants, or reading books, articles, and other resources. Survey respondents were also asked whether any of the following strategies were used to transfer knowledge to new board members during the search process in which they had been involved: board orientation process, mentor or buddy system, background documents about the search, retreat, independent study of the topic through a library or other source, external board colleagues, peer learning circles, recruitment specialist, or books, articles, and other resources. Finally, they were asked to briefly describe the orientation provided and the information given to the new member(s) about the search. Responses were analyzed to identify themes to explore in the next step, mini focus group sessions.

\section{Stage 2. Mini Focus Groups}

Six mini focus group sessions were held to facilitate two-way dialogue between 6 MacEwan and 6 non-MacEwan participants. Board chairs from public postsecondary institutions that had completed a presidential search process in the past five years and two recruitment specialists comprised the six external non-MacEwan study participants. Among the themes explored in the mini focus group sessions, participants spoke to the strategies used to learn about presidential search, what motivated them to participate in the study, as well as their experience with the survey, the focus group, and the study.

\section{Stage 3. One-on-One, Semi-Structured Interviews}

Each MacEwan participant, nine in total, was interviewed. The goal of the interview was to gain an understanding of how board members understood the elements involved in the topics of presidential search, board succession planning, and knowledge management practices. In particular, the interview was intended to achieve four specific aims: (a) understand the board member's level of knowledge, (b) better identify approaches board members found effective for learning about these topics, (c) receive suggestions to improve or enhance these activities, and (d) identify areas of growth to be explored in a modified World Café with all MacEwan board participants. Questions were posed about strategies typically used by board members to learn about presidential search (such as books, articles, other written resources, conferences). With the goal of this action research project being to provide a progressive learning experience for MacEwan board volunteers, feedback was solicited on the learning acquired through participating in the online survey and the mini focus group session. Participants were asked to indicate their level of knowledge on the three thematic areas prior to participating in the study, to i describe any changes in their level of knowledge resulting from participating in the study, and to make recommendations for a knowledge management strategy. The interviews allowed for reflection by MacEwan participants on learning acquired through the mini focus group session. They also enabled in-depth exploration of topics and themes as well as identification of gaps in knowledge. 


\section{Stage 4. Modified World Café}

Data from the survey, focus group sessions, and interviews were grouped according to the research topics. The researcher assessed and prioritized these data to identify six themes: board succession planning, presidential search and selection process and timeline, role of board and role of search committee, trust and confidentiality, knowledge management (board orientation, education, and development), and stakeholder consultation and engagement. For a World Café activity, a series of questions was developed for each theme. All nine MacEwan participants attended the modified World Café. At the conclusion, participants were invited to share their thoughts and observations on the World Café activity as well as their experience with the study.

\section{Principal Findings Related to the Learning Experience}

The findings were grouped into the following thematic areas: (a) knowledge management in terms of learning about governance roles within a board of governors, (b) knowledge transfer within a board of governors, (c) board succession planning, (d) specific knowledge acquired and transferred by participants on the topic of presidential search, and (e) MacEwan participants' overall learning experience with this study.

\section{Knowledge Management}

This study inquired about strategies used to acquire and transfer explicit and tacit knowledge during board orientation and as part of a board member's ongoing education and development during their term of appointment. Through the study, participants acquired additional explicit and implicit knowledge on board orientation, education, and development programs as well as presidential search. Each participant brought distinct knowledge to the collective team. By participants progressing through cycles of continual learning from the survey to the World Café, their individual knowledge evolved and was converted to shared knowledge. Participants critically assessed their orientation, education, and development programs; identified areas for improvement; and suggested strategies they could use to collectively and individually contribute to enhancing their programs.

\section{Knowledge Transfer}

The second theme explored in the study related to techniques and strategies used by boards to share knowledge. With membership on a board constantly changing, the researcher was interested in learning about factors that influence the transfer of knowledge within and between boards was an area of particular interest. The term knowledge transfer was explained by the researcher at the start of each focus group session, and participants discussed how it related to board succession planning, orientation, education, and development. Through the focus groups, interviews, and World Café, participants shared observations about the role of interpersonal trust (benevolence, competence), the use of social networks, and other factors that motivate and influence knowledge transfer. They extended the concept of trust to include confidentiality during a presidential search and discussed strategies for building and maintaining trust within the board as well as between the board, the search committee, and the internal institutional community. The experience of these participants reflected Chait et al.'s (2005) discussion of the value of having boards act as 
communities of practice, sharing knowledge, learning together and ultimately, creating the shared organizational intelligence that is a characteristic of effective boards.

\section{Board Succession Planning}

To continue the examination of knowledge transfer, this study inquired as to how boards develop and manage their succession plan, and how they identify best practices for board succession planning. Participants' responses revolved around three themes: (a) ongoing discussion within the board about board succession planning; (b) use of a framework to assess needs and develop strategies for recruitment and transition; and (c) thoughtful identification of specific qualities, skills, and characteristics of potential board members that align with institutional priorities. Although the approaches to board succession planning varied among the boards involved in the study, participants agreed there is value in having a framework for providing input into the recruitment of board members. Whether the framework was planned or ad hoc depended upon the specific needs and practices of the boards. Nonetheless, boards indicated they are taking a more active role in planning for their succession.

MacEwan participants critiqued the existing MacEwan board succession plan to identify areas for improvement and propose strategies they could collectively and individually undertake to enhance the plan. They also discussed and agreed on the importance of boards synchronizing their board succession plans with the timelines for an institution's presidential search exercise.

\section{Presidential Search}

Choosing the chief executive officer of a public postsecondary institution is a critical responsibility of a board. Board members may learn about the topic of presidential search through presentations at governance conferences or by reading governance books. Most often, however, boards learn about the topic at the time their institution is engaged in the recruitment of their next president. This study provided the MacEwan board with an opportunity to learn about presidential search by participating in a progressive learning experience at a time when MacEwan was not conducting a search. Through the four data collection methods, 18 distinct components of presidential search were identified and explored (see Table 2), and best practices for presidential search as well as strategies for learning about it were also studied.

\section{The Learning Experience of MacEwan Participants}

Among MacEwan participants who had read books, articles, and other resources, there was consensus around the need to receive good general, broad-based information, including advice to boards to carefully consider various elements of a search process: search committee composition and terms of reference, role of search firm, stakeholder input, transition plan, and the board's decision-making responsibility. Five of the nine interview participants reported having attended conference sessions on the topic of presidential search. They said they found these sessions provided good frameworks, with models and reference points, and were like focus groups in that they provided an opportunity to discuss experiences, share what they had read and ask questions, thereby building a broader base of knowledge. 
The online survey highlighted many aspects of the presidential search process that a board might consider. MacEwan interviewees viewed the survey as an excellent trigger, a helpful starting point, a good tactic to get cognition going, and a way to identify gaps in knowledge and areas needing improvement. The focus group sessions provided the greatest overall learning experience for MacEwan participants, who indicated that they found significant value in learning about another institution's search experience. The World Café provided the greatest opportunity for group learning by MacEwan participants on specific aspects of the presidential search process and demonstrated how, by participating in the research exercise and progressing through cycles of continuous learning from the survey to the World Café, individual knowledge evolved and was converted to shared knowledge.

As a result of participating in this study, MacEwan participants extensively expanded their knowledge about a repertoire of elements associated with conducting a presidential search within a postsecondary environment. They accomplished this by reflecting upon what they had individually learned from the experiences of others, sharing this knowledge with their board colleagues, and having conversations to create a shared understanding of the complexities of a presidential search. They developed consensus on several elements and acknowledged a need for further dialogue on others.

\section{Feedback from MacEwan Participants on Experience with the Study}

At the conclusion of the World Café, the MacEwan participants shared their thoughts and observations on the World Café activity as well as their experience with the study. Following are some of the comments received:

It's been a fabulous learning process for me. You've really nudged all of us to think about these things at an appropriate time. Thank you for doing that, it's great. (Participant WC741)

Very well organized project and a great learning process. (Participant WC14)

Everyone knows how I feel. We've been happy to assist with your project. This has been a good learning experience for all of us. (Participant WC443)

I echo everyone's comments. It's been a great exercise. (Participant $\mathrm{WC}_{328}$ )

This will cause us to strengthen all the processes that we touch. I've been most impressed. You've emptied my brain on everything on this process. You've heightened the awareness of the whole board around these subjects. You've introduced me to subjects I hadn't even thought about and I'm quite surprised. I think it's a wonderful research project that you carried out perfectly. (Participant WC937)

The whole thing is just absolutely fantastic and has been so much better than the conference workshop we attended on presidential search. You need to take this on the road. This has been a master's made in heaven for you and for our board. I'm so grateful you chose these topics and we had the opportunity to participate in this experience. (Participant WC834) 
Reflecting on these comments, the researcher concluded that the experience of participating in an action research project that utilized various interactive and progressive data-gathering methods significantly contributed to the learning of each MacEwan participant and of the MacEwan board as a group. However, questions remain as to whether participants' high level of engagement was a result of being provided with the opportunity to share their thoughts and ideas within the auspices of research. Would the same degree of learning have occurred through the efforts of a consultant rather than those of a graduate student with whom these board members had a relationship? These questions may be areas for exploration in future research projects.

\section{Study Recommendations Related to the Learning Experience}

\section{Explore and Activate Opportunities to Facilitate Individual and Group Learning}

This study utilized an action research methodology to provide a unique opportunity for a group of people-MacEwan board members-to step out of their comfort zone and come together to learn about the specific governance role of presidential search at a time when the institution was not involved in conducting a search. This research demonstrated that knowledge acquisition and transfer can take place within a constructed group learning process, particularly when the following elements are in place: (a) the topic chosen for knowledge transfer is salient, (b) the process used to acquire and transfer the knowledge is unique, as was demonstrated by the opportunity provided through this graduate study, (c) the timing of the learning opportunity is right, and (d) the learning process is equitable between participants and researcher-both parties gain useful knowledge about a process in which they would engage. The researcher recommended that the MacEwan board apply these principles when choosing learning activities and embrace the opportunity to use non-traditional group interaction techniques to facilitate learning. It was further suggested that the board incorporate an assessment of individual learning into its annual evaluation activity, whereby members would identify any new learning that has taken place in the preceding year. When developing or enhancing its orientation and education strategies, consideration should be given to the distinctive characteristics and needs that each board member brings to the group.

\section{Value and Support Knowledge Management as an Integral Component of Good Governance}

A board of governors requires an array of skills and knowledge to perform its role in achieving an organization's goals. Individual board members draw upon their personal and professional backgrounds to bring certain skills and knowledge to board deliberations. Board members function at the highest decision-making level of an organization,

yet due to their volunteer roles and the regulations surrounding board governance, they are temporary members of the organization. During their tenure, they acquire significant knowledge about their organization's operations and culture as well as trends and issues associated with the field in which the organization operates. Through the experience of serving on a governance board, members individually and collectively garner additional knowledge and skills within a different context-board governance. 
Following is some advice to boards relative to valuing and supporting knowledge management as an integral component of good governance:

- Create a knowledge management strategy to continually cultivate and integrate individual and collective knowledge into intellectual capital.

- Observe when board members are absent from discussions and follow up with them to ensure they become informed on the topic and any related decision.

- Develop specific knowledge components related to governance roles, such as board succession planning, orientation, education, and development.

- Be alert to the impact of turnover on each individual, within the group as a whole, upon the institution, as well as to the integrity of the board's knowledge base. Develop strategies to facilitate ongoing learning and sharing of knowledge so as to keep overall intellectual capital intact.

\section{Suggestions for Further Research}

This project is evidence that participating in an action research project can have a significant and positive impact on board members' learning, both individually and as a group. One question to pose in a follow-up study with these participants is whether this impact resulted from participating in a higher-level learning experience through a graduate research project, was related to the study methodologies (i.e., survey, focus group, interview, and World Café group activity), or was due to other factors. It would be helpful to expand the scope of the study on a national and North America-wide basis to inform board governance activities on a broader basis.

Although board members occasionally complete surveys on governance topics, participation in action research is not common practice. One area to explore is how boards can expand their education and development role to include action learning. It would be interesting to assess board members' motivation for, and success with, personally taking on tasks to gather knowledge. Another question to consider is whether knowledge acquisition and transfer can be outsourced. Do individuals experience the same results through a learning exercise conducted by a paid professional such as a consultant, in contrast to a graduate research project carried out by someone with whom they have an existing professional relationship? What role, if any, does understanding the context of the organization play in successfully transferring knowledge? Does having one person serve as a constant factor throughout a knowledge transfer experience contribute to the degree of learning experienced by each participant and by the group?

\section{Conclusion}

Recruiting and selecting a president is a critical responsibility of a board of governors, which should be approached as a thoughtful learning experience. Normally, boards of governors learn about presidential search while they are engaged in a recruitment process or through presentations provided at governance conferences. Seeking knowledge about this topic through a proactive and targeted learning experience is not standard practice. This study provided a timely and unique opportunity through an action research exercise that used knowledge management as a framework for board members at Grant MacEwan College and elsewhere to gain insights from, and share findings with, one another about a topic that is a fundamental board responsibility-choosing the institution's top leader. 
All participants in this study were enthusiastic contributors whose candid observations demonstrated a commitment to, and universal belief in, principles of governance. They found common ground on many aspects of their practices associated with recruitment, orientation, and education of board members. Participants gained a better understanding of the complexity of these important board responsibilities and an appreciation for the roles they can play individually and collectively in facilitating them. MacEwan board volunteers and external participants reported acquiring both explicit and implicit knowledge through a variety of formal and informal tools, techniques, and experiences.

Based upon feedback received, the experience of participating in an action research project that utilized various interactive and progressive data-gathering methods significantly contributed to the learning of each MacEwan participant and to the MacEwan board as a group. This study also added to existing literature on board succession planning and presidential search within the postsecondary sector. It contributed to research on the topics of knowledge management and knowledge transfer, extended this to the context of postsecondary board governance, and identified areas for potential further research.

"Effective boards place a high value on their learning" (Smith, 2000, p. 193). This was a unique and value-added learning opportunity for the MacEwan board members, enabling them to examine several governance roles and responsibilities, including presidential search. Feedback from participants about the interactive and progressive nature of the methods chosen for this project validated what Abrams, Cross, Lesser, and Levin (2003) found: "Numerous studies confirm that people prefer to get useful information and advice from other people" (p. 73). The project's participative approach also aligned with Wheatley's (2006) prescription: "[T] he best way to create ownership is to have those responsible for implementation develop the plan themselves" (p. 68).

\section{References}

Abrams, L. C., Cross, R., Lesser, E., \& Levin, D. Z. (2003). Nurturing interpersonal trust in knowledge-sharing networks. Academy of Management Executive, 17(4), 64-77.

Argote, L. (1999). Organizational learning: Creating, retaining and transferring knowledge. Norwell, MA: Kluwer Academic.

Berg, B. L. (2004). Qualitative research methods for the social sciences (5th ed.). Boston, MA: Pearson Education.

Block McLaughlin, J. (1993). Selecting the chief executive. In Richard T. Ingram \& associates (Eds.), Governing public colleges and universities: A handbook for trustees, chief executives, and other campus leaders (1st ed., pp. 112-125). San Francisco, CA: Jossey-Bass \& the Association of Governing Boards of Universities and Colleges.

Bugg, G., \& Dallhoff, S. (2006). National study of board governance practices in the nonprofit and voluntary sector in Canada. Toronto, ON: Strategic Leverage Partners \& Centre for Voluntary Sector Research and Development. Retrieved September 1, 2016, from http:// www.strategicleveragepartners.com/bhg768kjmhgvxxyxzwq/National_Study_of_Board_ Governance_Practices_in_the_Non-Profit_and_Voluntary_Sector_in_Canada.PDF

Chait, R. P., Holland, T. P., \& Taylor, B. E. (1993). The effective board of trustees. Phoenix, AZ: Oryx Press. 
Chait, R. P., Ryan, W. P., \& Taylor, B. E. (2005). Governance as leadership: Reframing the work of nonprofit boards. Hoboken, NJ: John Wiley \& Sons.

Glesne, C. (2006). Becoming qualitative researchers: An introduction (3rd ed.). New York, NY: Longman.

Huysman, M., \& de Wit, D. (2003). A critical evaluation of knowledge management practices. In M. S. Ackerman, V. Pipek, \& V. Wulf (Eds.), Sharing expertise: Beyond knowledge management (pp. 27-51). Retrieved from NetLibrary database

Lucas, L. M., \& Ogilvie, D. (2006). Things are not always what they seem: How reputations, culture, and incentives influence knowledge transfer. The Learning Organization, 13(1), 7-24.

Neff, C. B., \& Leondar, B. (1992). Presidential search: A guide to the process of selecting and appointing college and university presidents. Washington, DC: Association of Governing Boards of Universities and Colleges.

Nonaka, I. (2002). A dynamic theory of organizational knowledge creation. In C. W. Choo \& N. Bontis (Eds.), The strategic management of intellectual capital and organizational knowledge (pp. 437-462). New York, NY: Oxford University Press.

Post-secondary Learning Act, Statutes of Alberta (2003, c. P-19.5). Retrieved March 29, 2015, from http://www.qp.alberta.ca/documents/acts/p19p5.pdf

Smith, C. J. (2000). Trusteeship in community colleges: A guide to effective governance. Washington, DC: Association of Community College Trustees.

Snowden, D. (2005). From atomism to networks in social systems. The Learning Organization, 12(6), 552-562.

Wenger, E. (2004, January/February). Knowledge management as a doughnut: Shaping your knowledge strategy through communities of practice. Ivey Business Journal Online, 1-8. Retrieved from ProQuest database

Wheatley, M. J. (2006). Leadership and the new science: Discovering order in a chaotic world (3rd ed.). San Francisco, CA: Berrett-Koehler.

Williams, R. (2006). Narratives of knowledge and intelligence ... beyond the tacit and explicit. Journal of Knowledge Management, 10(4), 81-99.

\section{Notes}

1. On September 24, 2009, Grant MacEwan College was renamed to Grant MacEwan University through Order-In-Council 481/2009 issued by the Lieutenant Governor in Council. In 2013 the university was rebranded MacEwan University for public communication and marketing purposes, though Grant MacEwan University remains its official name.

2. Remarque : le 24 septembre 2009, l'émission du décret 481/2009 par le lieutenantgouverneur en conseil a modifié la dénomination du Grant MacEwan College, le renommant Grant MacEwan University.

3. A World Café is a group dialogue process where people gather at café tables, each with a theme. With a host remaining at the table, participants move between café tables and 
have conversations about the assigned theme. This results in a cross-pollination of perspectives, observations, and ideas as well as new insights. While this technique is normally used with larger groups, it was modified to involve the nine MacEwan participants.

\section{Contact Information}

Margo Baptista

Grant MacEwan University

baptistam@macewan.ca

Margo Baptista is the university secretary at Grant MacEwan University. Throughout her career in postsecondary governance, in addition to being a governance practitioner, she has researched and presented in Canada and the United States on a wide range of board governance topics, such as roles and responsibilities, recruitment, orientation, succession planning, development, presidential search, evaluation (board and president), and the role of board professional staff. For her graduate research study, she utilized action research and knowledge management theory to explore the governance roles of board succession planning and presidential search within the Alberta and British Columbia public postsecondary systems. 


\section{APPENDIX A: SURVEY QUESTIONS}

1. Please indicate the number of years of experience you have as a board member with:

- public not-for-profit organizations

- private for-profit organizations

2. Are you currently a member of (indicate all that apply):

- a public not-for-profit board in the post-secondary sector

- a public not-for-profit board in another sector (i.e,. community league)

- a private for-profit board

3. Briefly describe the mandate(s) of the organization(s).

4. What is the size (estimate) of the organization(s) in terms of the following, where applicable and where the information is publicly available?

- number of employees

- number of students

- annual operating budget

5. Describe the composition of the board(s), e.g. publicly appointed members, privately appointed members, elected members, internal constituent members, etc.

6. Has one or more of your organization(s) conducted a presidential search in the past 5 year? If so, indicate the year in which it was done?

7. What aspects of a presidential search process were used in the last search (indicate all that apply):

- Board visioning exercise

- Autonomous search committee

- Board search committee

- Assistance from external recruitment specialist(s)

- Assistance from government agency

- Interim president

- Internal communication strategy

- Internal consultation process
- Engage constituents

- Consultation with current leadership team

- Public forums eg. open question and answer sessions

- Advice from informal networks

- Position profile

- Transition plan for new president

- Public website providing details of search

- Other, please describe

8. How did you learn about conducting a presidential search process and all of the elements that are involved in this (indicate all that apply)?

- Past experience with a search process while on this board

- Past experience with a search process while on another board

- Board education/development plan

- Attend a conference

- Read books, articles and other written resources

- Attend presentations by industry experts

- Attend presentations by paid consultants

- Information provided by Human Resources Department

- Participate in board colleague networks 
- Participate in conversations with business associates

- Participate in conversations with friends

- Other (please describe)

9. Does the organization have a policy, practice, plan or set of guidelines in place regarding presidential search. If yes, what are these, and may we have a copy of any written documents on this? (Please forward the document(s) by email to xxxxxx@ xxxxxx.xx)

10. Was your last experience with a presidential search a satisfying, productive, and happy one? Please describe one event that stands out in your mind as representing how you felt about this experience.

11. In your opinion, what are the best practices that should comprise a presidential search process?

12. Did the board debrief on the search process/ If so, what did you l earn from the debriefing experience about the rest of the team's experience? Were there elements of the search your team did well that you would do again in the future, and/or would not do again? Debriefing process, please describe

13. Did the membership of the board change during the search process? If so, was there a Board succession plan in place? If yes, how and when was this developed? Succession plan details

14. Were any of the following strategies used to transfer knowledge to new board members during the search process (indicate all that apply)?

- Board orientation process

- Mentor or buddy system

- Books, articles, and other written resources

- Background documents about the search

- Retreat

- Independent study of the topic through a library or other source

- External board colleagues

- Peer learning circles

- Recruitment specialist

15. Briefly describe the orientation given to the new member(s) about the search.

16. Which of the following aspects apply to your board succession plan (indicate all that apply)?

- We have a formal board succession plan

- We have an informal board succession plan

- Our board succession plan is ad hoc, created as required

- Our board conducts an annual analysis of board competencies and needs

- Our board conducts an ad hoc analysis of board competencies and needs, created as required

- We have a nominating or governance committee

- We have an orientation program

- We have an orientation manual

- We have an education/development program for our members

- Our board staggers or strategically times its terms of appointment

- We have an ongoing program to identify potential board members that is aligned 
with our strategic interests

- We identify potential board members on an ad hoc, as required basis

17. Does the organization have a policy, practice, plan or set of guidelines in place regarding board succession planning (recruitment, orientation, etc). If yes, what are these and may we have a copy of any written documents on this? (Please forward the document(s) by email to xxxxxx@xxxxxxx.xx)

18. In your opinion, what are the best practices related to transferring knowledge within a board?

19. Do you have any additional comments or thoughts you would like to share about the topics of presidential search, board succession planning, and knowledge transfer within boards?

20. Would you be willing to participate in a subsequent mini focus group (two participants and the researcher) associated with this project? If yes, please provide your name and a way for us to contact you: phone number or email. By saying yes and disclosing your name and contact information, you are also agreeing to maintain anonymity of the other participants in your mini focus group session. 